\title{
Socio Cultural Influences on Online Shopping Behaviour
}

\author{
Zaid Ahmad Ansari \\ Department of Business Administration \\ College of Business and Economics, Qassim University, Saudi Arabia
}

\section{Keywords}

Saudi Arabia, Socio Cultural Factors, Online Shopping Behaviour, Consumers

\begin{abstract}
Purpose: The study had been carried out with the aim to find out the influence of Customers;' Socio Cultural Factors on their Online Shopping Behaviour. The findings of the study would be very fruitful to company owners who sell their products online by making them aware about customers' online shopping behaviour in respect to their social and cultural factors.

Methodology: The study is quantitative and descriptive in nature, based on primary data collected from the various people of Saudi Arabia and Non-Saudi nationals. A structured close ended questionnaire has been used in this study as research instrument based on 5-point Likert Scale from 5 to 1. Total 400 respondents had been participated in the present research work. Analysis has been made with the help of various statistical tools and techniques i.e. Factor Analysis, Mean and Standard Deviation.

Findings: Present study concludes that Customers' Socio-Cultural Factors has a significant influence on Online Shopping Behaviour. Total three factors captioned Social Factors, Cultural factors and Social Class with 4, 8 and 5 variables respectively had been extracted with a high degree of reliability. Among all these three factors Cultural Factors and Social Class with three variables each has a significant influence on online shopping behaviour of customers. Rest of the findings has been discussed in the research paper.

Study Limitations: Present Study had been carried out in Saudi Arabia and the analysis results of this study could not be inferred in other parts of the world.
\end{abstract}

Corresponding author: Zaid Ahmad Ansari

Email addresses for corresponding author: drzaidansari@gmail.com

First submission received: $2^{\text {nd }}$ February 2018

Revised submission received: $14^{\text {th }}$ May 2018

Accepted: 22 $2^{\text {nd }}$ May 2018

\section{Introduction}

Internet influenced every aspects of life across the globe including the method of conducting business, communication, business relations. Ecommerce is one such result of internet and information technology development. The business transactions have gone from traditional mode of personal contacts to virtual mode where the two parties transact, negotiate over the internet and do not come in personal contact of each other. Gradually online shopping evolved rapidly giving birth to many e-retailers starting from developed countries followed by the developing countries such as India, China, and other middleeast countries including Saudi Arabia. Online shopping is on rise globally. Dawn of $21^{\text {st }}$ century witnessed rampant and rapid development in the field of e-commerce and success was achieved by many enterprises in western countries. According to Wallis (2006) internet sales to households from the UK nonfinancial sector stood at pound 4billion which increased to $£ 18$ billion in 2004. The growth in internet sales between 2003 and 2004 was over 67\%, a clear mandate that internet sales was there to stay. Information Data Center predicted that e-commerce spending will reach $\$ 496.7$ billion in the United states and $\$ 1.3$ trillion globally by the year 2009. The benefits of online shopping added new customers on continuous basis evident from growth in online retail sales and in 2017 it was estimated to be \$2197 trillion and grow to $\$ 2489$ trillion in 2018 (Invespro.com, 2018). Study carried out by Ansari \& Alhazemi, 2016 demonstrated that the value of online transaction has grown exponentially to US\$1471 billion in 2015 and is projected to grow to US\$ 2365 billion in 2018. Online shopping is a growing business around the globe and approximately 41 percent of global internet users have purchased products online in 2013. 
In current business environment online shopping is tremendously in boom in the field of EBusiness and is definitely going to be the future shopping method in the world. Large number of retailers started their online portals to sell their products/services on-line and few others are selling products through some common online shopping website known as e-retailers. Researches show, ecommerce is a huge market and it is getting bigger day by day (Muthumani \& Rajayogan, 2017). The current business environment is very dynamic. Online business is growing fast everywhere in the world. Competition in the industry is increasing also the customer demands. The reasons for fast growth in online shopping due to its benefits as a research demonstrated that online shopping is better than conventional shopping due to convenience and ease of use (Nazir, Tayyab, Sajid, Rashid and Javed, 2012). For private consumers around the globe the most well-known form of e-commerce falls into the business to consumer (B2C) category, also known as online retail or online shopping. The growth of interest in the internet as a shopping and purchasing medium fascinated practitioners and researchers alike. Its rapid growth posed intriguing questions for academic research (Yin-Fah, \& Hooi-Choo, 2010). The researchers got interested in finding what type of customers purchase online, what factors such as income, age, education influence the online shopping, what the reasons for buying online and what could be the reasons for not buying online. These and many became the subject of online shopping. A research showed that online shopping depends upon the view of the consumers regarding the activities carried out on the internet as opposed to conventional shopping environments. A consumer who perceives online shopping as beneficial is more inclined to make online purchases (Soopramanien \& Robertson, 2007). The online shopping is done by human beings and there are factors involved in online shopping behaviour of a particular individual. Researchers in this field have identified many factors that influence a consumer's purchases decision and online buying behavior (Goldsmith, Bridges, and Freden, 2001; Vellido, Lisboa, and Meehan, 2000). Adnan (2014) established that there are some psychological factors that had a positive impact on consumer attitudes and buying behaviour. A study revealed that some of the reasons for adoption of online shopping include time saving, easy comparison of alternative products, fairer prices of online goods, expert/user review of products and access to a market without borders (Ngugi, 2014). Some demographic factors i.e. social factor had a significant effect on the behaviour of online shoppers Nazir et al. (2012). Some researchers proposed that the consumer's own characteristics play an important role in his/her propensity to engage in internet transactions (Jarvenpaa and Grazioli, 1999). According to the findings of Ansari (2016), conducted in Saudi Arabia, Saudis were more interested in online shopping compared to non-Saudis living in Saudi Arabia, it further showed that gender difference also existed as females were comparatively more interested than the males in online shopping.

The continuous growth and popularity of ecommerce promised huge potential for the business organizations and topic of research to the researchers. Since inception of e-commerce and online shopping, researchers have been investigating various aspect of ecommerce including trust in online shopping, benefits of online shopping, risks of online shopping, etc. The researcher in this paper attempted to study the influence of yet other important factors influencing consumer's behaviour namely; social factors, cultural factors, and social class of the online buyers in online shopping.

\section{Review of Previous Literature}

According to Elliot and Fowell (2009) online shopping is emerging fast and more and more consumers are shopping online compared to visiting the traditional shops. Some early studies on online shopping showed that initial online shoppers were more educated (Li et., 1999), had higher socioeconomic status (Tan, 1999), were younger than average and more likely to be male (Korgaonkar and Wolin, 1999). Some other studies investigated the differences in e-purchase decisions according to different demographic factors (Zheng, 2006; Rodgers \& Harris, 2003; Slyke, Lou, Belanger, and Sridhar, 2002). In their study Bae \& Lee (2011); Hui \& Wang (2007); and Alsamadi (2002) found no difference between male and female in making e-purchase transactions. Seiders, Voss, Grewal and Gredfrey (2005) show in their study that age made a statistically significant difference in customer' e-purchase behaviour. The study also demonstrated a statistically significant difference in customer's e-purchase transactions due to income; the higher the income, the higher the e-purchase transactions. However, (Seiders et al, 2005) study found no significant differences in e-purchase transactions due to education. In their study Case, Burns, and Dick, (2001) revealed that majority of online purchaser are male candidates. According to 
Hasslinger, Hadzic and Obazo, (2007) customers with higher educational degree with high income showed positive attitude and behaviour towards internet buying. Thus, demographic factors such as age, income and education of the customers substantially impact the online behaviour.

Initially the online shoppers tended to differ from traditional shoppers. The innovator group of customers of online shopping tended to be more educated (Li. and Russel, 1999), higher socio-economic status (Tan, 1999), younger than average and more likely to be male (Korgaonar and Wolin, 1999). While there are many hurdles to the internationalization process an internet week survey found that one of the major obstacles for companies was understanding of the cultural differences between countries (Violino, 2001). Falode, Amubode, and Ogunduyile, (2016) revealed in their research that females are more expected to be interested in and knowledgeable about fashion and clothing trends and also in online purchasing. In his study Bashir (2013) concluded that behavior of individual consumers or groups may differ depending upon various internal as well as external factors such as personality, psychological and social drives, which influence the decision making and actual purchase behaviour of individual. Study carried out by Ansari, (2016) in Saudi Arabia revealed that Saudi nationals were more interested in shopping online compared to non-Saudis living there. Saudi females were found more interested in online shopping in comparison to males. People age of 25 years and more than 25 years were more interested in shopping online compared to people less than 25 years. Education of the customers positively influenced their online shopping decision, respondents with bachelors' degree and more show interest in online shopping. Another demographic variable 'Employment' was also influencing the online shopping behaviour of consumers. Employed people were found more interested in online shopping in comparison of unemployed ones. Gender affects the relationship between consumer online shopping orientation and purchase behaviour. Male have a higher convenience orientation than females (Chen \& Hun, 2015). In their research work Case et al. (2001) demonstrated that males represent the majority of online purchase. Respondents' age, income and educational level were strongly influencing the online buying behavior.

Developed countries were leading in online shopping compared to developing or under developed countries. The developed countries managed carefully the privacy and use of personal information of the customers (Reichheld and Scefter, 2000). Studies carried out in USA taking into consideration the demographic factors indicated that the online population was not representative of the general population; specially, the online population tended to be disproportionately white, male, educated, and affluent (Ansari, 2016).

Hasslinger et al. (2007) show in their work that educated consumers with high income appeared to express positive attitude and behavior towards Internet buying and they made distinction between the consumer characteristics that are explained by cultural, social, personal and psychological characteristics, and online consumer characteristics. Mareeswaran \& Sunderaraj (2017) found relationship between the occupation of the respondents and their preference to make online shopping, especially if the occupation pay high, there is more chance of online shopping. A positive association was also found between age group and awareness about online shopping. A significant relationship was also found between educational level of the respondents and their usage of internet. A higher level of literacy leads the internet use for online shopping. There was found a moderating relationship between demographic variables under study which moderates the relationship between attitude and behavioral intention of online consumer. Study results of Farooqui and Ansari (2017) conclude that the person from age group of 25-50 were the most regular online shoppers and people below and higher that age group of 25-50 were not keen of online shopping. High income group of people was purchasing much online that low income group of people. Demographic factor gender had a moderating impact on peoples' attitude towards online shopping. Study carried out by Muthumani \& Rajayogan (2017) a significant influence of demographic factors on consumers' online shopping behaviour. The ANOVA results for consumers' response across different demographics factors shows that gender does impact control of internet and Frequency of online purchase. Occupation of consumers had not any significant influence on online purchase behaviour. Income has a significant impact on impact Frequency of online purchase of consumers. The results show that there is no significant impact across the various age groups (Muthumani \& Rajayogan, 2017). According to Ferrietal, (2008) consumers are more and more attracted by purchases on the internet due to its convenience in terms of times and costs, it further showed that before making an 
online purchase consumer ask the opinion of their friends or reference group as the perceived risk is higher than traditional purchases.

Consumer purchases over the internet continue to grow rapidly worldwide, particularly among younger buyer. In United States for instance, 25 to 34 years old already make more than a quarter of their purchases online, and new technologies - such as 4G phones and geolocation apps will spur growth (Walker and Mullins, 2014). The above literature sufficiently explains the reasons for online shopping and also the type of people who usually engages in online shopping. However, the researcher in this study investigated the influence of some other related factors such as social factors, reference groups, and social class factors as these factors influence the shopping behaviour in traditional shops.

\section{Research Methodology}

3.1 Objectives of the Study: The objective of the present study was to find out influence of Socio-Cultural factors of the respondents on their online shopping behaviour.

3.2 Hypothesis of the Study: Taking into consideration the objective of the study, hypothesis 'Socio Cultural factors of the respondents have no significant influence on their online shopping behaviour'.

3.3 Research Instrument: To assess the opinion of the respondents about their online shopping behaviour a structured close ended questionnaire was used. The questionnaire was based on five-point Likert Scale ranging from 5 to 1 . Since in the survey demographic factors are important, some demographic factors i.e. Nationality, Gender, Age, Education, Marital status, Occupation, and Income of the respondents had been considered. For increase and ease in response from respondents, questionnaire was translated in Arabic Language.

3.4 Respondents Data and Select Variables: Present study had been carried out in Saudi Arabia. Respondents were Saudi citizens as well as non-Saudi expatriates working there. A total number of 400 respondents have been considered in present survey. Selected variables for the study had been carefully extracted from related literatures. Variables which can fit the objectives of the study had been considered.

3.5 Analysis Tools and Techniques: As per the requirement of objectives of the study necessary tools and techniques had been administered. Factors Analysis technique had been used for extracting the factors and Cronbach Alpha to know the reliability of instrument. For further analysis and interpretation of results statistical tools like Mean and Standard Deviation has been considered.

4. Data Analysis and Empirical Results: The empirical results from the analysis are as follows:

4.1 Socio Cultural Description of Respondents

Table: 1 demonstrates the Socio Cultural Characteristics of respondents. Present study includes total number of 400 respondents in which majority of the respondents $(345,86.25 \%)$ were Saudi nationals and rest of the respondents $(55,13.75 \%)$ were from outside of Saudi Arabia. In gender criteria maximum respondents $(319,79.75 \%)$ were male and only $(81,20.25 \%)$ were female. In case of age group maximum number of respondents $(178,44.50 \%)$ was from 20 to 24 years of age group which shows that most of the respondents were very young and the only (31,7.75\%) respondents belongs from age group of $40 \&$ above. Educational Status as shown in Table: 1 reveals that most of the respondents $(186,46.50 \%)$ were Bachelors on second position (141,35.25\%) were High School pass respondents. Minimum percentage of respondents in educational qualification was of No Formal Education holders' group that was $(3, .75 \%)$. In marital status group most of the respondents $(205,51.30 \%)$ were single and remaining persons (195, $48.80 \%$ ) were married. As far the occupation of respondents is concerned majority of the respondents (199, $49.75 \%)$ were students and on second position were employed people (161, 40.25\%). In this criterion minimum number of respondents $(7,7.75 \%)$ were from unemployed group. In income status of respondents' maximum percentage $(221,55.25 \%)$ were those who are earning less than 5000 Saudi Arabian Riyals. The least percentage of respondents $(17,4.25 \%)$ had been found those who are earning more than 20000 SAR. 


\begin{tabular}{|c|c|c|}
\hline Profile & $\mathrm{N}$ & $\%$ \\
\hline \multicolumn{3}{|l|}{ Nationality } \\
\hline Saudi & 345 & 86.25 \\
\hline Non-Saudi & 55 & 13.75 \\
\hline \multicolumn{3}{|l|}{ Gender } \\
\hline Male & 319 & 79.75 \\
\hline Female & 81 & 20.25 \\
\hline \multicolumn{3}{|l|}{ Age } \\
\hline 15 to 19 & 29 & 7.25 \\
\hline 20 to 24 & 178 & 44.50 \\
\hline 25 to 29 & 81 & 20.25 \\
\hline 30 to 34 & 41 & 10.25 \\
\hline 35 to 39 & 40 & 10.00 \\
\hline 40 and above & 31 & 7.75 \\
\hline \multicolumn{3}{|l|}{ Education } \\
\hline Intermediate & 24 & 6.00 \\
\hline High School & 141 & 35.25 \\
\hline Bachelors & 186 & 46.50 \\
\hline Masters & 31 & 7.75 \\
\hline Ph.D. & 15 & 3.75 \\
\hline No Formal Education & 3 & 0.75 \\
\hline \multicolumn{3}{|l|}{ Marital status } \\
\hline Married & 195 & 48.8 \\
\hline Single & 205 & 51.3 \\
\hline \multicolumn{3}{|l|}{ Occupation } \\
\hline Student & 199 & 49.75 \\
\hline Employed & 161 & 40.25 \\
\hline Self Employed & 19 & 4.75 \\
\hline Housewife & 14 & 3.50 \\
\hline Unemployed & 7 & 1.75 \\
\hline \multicolumn{3}{|l|}{ Income } \\
\hline Less than SAR 5000 & 221 & 55.25 \\
\hline 5001 to 10000 & 87 & 21.75 \\
\hline 10001 to 15000 & 48 & 12.00 \\
\hline 15100 to 20000 & 27 & 6.75 \\
\hline More than 20000 & 17 & 4.25 \\
\hline
\end{tabular}

Table 1: Socio Cultural Characteristics of Respondents

\subsection{Factor Extraction and Test of Reliability}

Table 2 below demonstrate that three factors i.e. Social Factors, Cultural Factors and Social Class had been extracted from the research instrument with the help of Factor Analysis method. First factor Social Factors includes four variables namely; Your Reference groups, Your Friends, Your family and Your Status with Alpha Value of .884. Second factor named Cultural factors have eight variables which is maximum among all three factors i.e. eight variables captioned Respondents' Values, Language, Customs, their Country Laws, Nationality groups, Racial groups, Religious groups and Geographical areas enjoying Cronbach's Alpha Value of .880. The third factor termed Social Class includes five variables named Education, Occupation, Income, Family Background and Residence location which holds the maximum Alpha value of .902. In all the three cases the Alpha value is above .80 which shows a high degree of reliability of the instrument used in this study. 


\begin{tabular}{|c|c|c|}
\hline Factor Description & Alpha Value & No. of Variables \\
\hline $\begin{array}{l}\text { 1. SOCIAL FACTORS } \\
\text { Your Reference groups } \\
\text { Your Friends } \\
\text { Your Family } \\
\text { Your Status }\end{array}$ & .884 & 4 \\
\hline $\begin{array}{l}\text { 2. CULTURAL FACTORS } \\
\text { Your Values } \\
\text { Your Language } \\
\text { Your Customs } \\
\text { Your country laws } \\
\text { Nationality groups } \\
\text { Racial groups } \\
\text { Religious groups } \\
\text { Geographical areas } \\
\end{array}$ & .880 & 8 \\
\hline $\begin{array}{l}\text { 3. SOCIAL CLASS } \\
\text { Education } \\
\text { Occupation } \\
\text { Income } \\
\text { Family Background } \\
\text { Residence location }\end{array}$ & .902 & 5 \\
\hline
\end{tabular}

Table: 2 Cronbach's Alpha Reliability Test

\subsection{Analysis of Extracted Three Factors (Social Factors, Cultural Factors and Social Class) 4.3.1 Social Factors}

Social factors are very important factor in consumer behaviour. In the present analysis part Table: 3 show that all four variables of the 'Social Factors' i.e. (Your Reference Group, M=3.81; Your Friends, M=3.87; Your Family, M=3.98; and Your Status, $M=3.85$ ) have the Mean value below 4.00. In this case it could be inferred that this factor does not play very important role in influencing the customers shopping online.

\begin{tabular}{|l|l|l|}
\hline Variables Name & Mean & Std. Dev \\
\hline Your Reference groups & 3.81 & 1.295 \\
\hline Your Friends & 3.87 & 1.235 \\
\hline Your Family & 3.98 & 1.177 \\
\hline Your Status & 3.85 & 1.265 \\
\hline
\end{tabular}

Table: 3 Social Factors and Online Shopping Behaviour

\subsubsection{Cultural Factors and Online Shopping Behaviour}

Table: 4 show Cultural Factors with the mean value of its various variables i.e. (Your Values, $\mathrm{M}=4.07$; Your Language, $\mathrm{M}=4.05$; Your Custom, $\mathrm{M=3.82}$; Your Country Law, $\mathrm{M}=4.06$; Nationality Groups, $\mathrm{M}=3.21$; Racial Groups, $\mathrm{M}=3.28$ and Geographical Area, $\mathrm{M}=3.39$. Out of these variables three variables captioned Your Values, $M=4.07$; Your Language, $M=4.05$ and Your Country Law, $M=4.06$ were found with mean value above 4 . These variables are found much more significant in influencing the online shopping behaviour of the respondents.

\begin{tabular}{|l|l|l|}
\hline Variable Name & Mean & Std. Deviation \\
\hline Your Values & 4.07 & 1.161 \\
\hline Your Language & 4.05 & 1.168 \\
\hline Your Customs & 3.82 & 1.284 \\
\hline Your Country Law & 4.06 & 1.130 \\
\hline Nationality Groups & 3.21 & 1.577 \\
\hline Racial Groups & 3.03 & 1.558 \\
\hline Religious Group & 3.28 & 1.517 \\
\hline Geographical Area & 3.39 & 1.432 \\
\hline
\end{tabular}

Table: 4 Cultural Factors and Online Shopping Behaviour 


\subsubsection{Social Class Factors and Online Shopping Behaviour}

Table: 5 demonstrate Social Class factors of respondents and it's including variables i.e. (Education, $\mathrm{M}=4.08$; Occupation, $\mathrm{M}=4.00$; Income, $\mathrm{M}=4.17$; Family Background, $\mathrm{M}=3.89$ and Residence

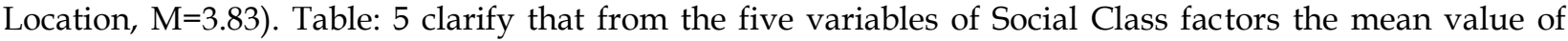
three variables are more than 4 indicating its influence on the online shopping behaviour. These three factors are Education, $\mathrm{M}=4.08$; Occupation, $\mathrm{M}=4.00$, and Income, $\mathrm{M}=4.17$, however the Family Background of the customer and their Residence Area do not influence much their online shopping behaviour indicated mean value of 3.89 and 3.83 respectively.

\begin{tabular}{|l|l|l|}
\hline Variables name & Mean & Std. Dev \\
\hline Education & 4.08 & 1.220 \\
\hline Occupation & 4.00 & 1.207 \\
\hline Income & 4.17 & 1.092 \\
\hline Family Background & 3.89 & 1.228 \\
\hline Residence location & 3.83 & 1.303 \\
\hline
\end{tabular}

Table: 5 Social Class Factors and Online Shopping Behaviour

\section{Discussion}

Purpose of the present research was to assess the influence of respondents' Socio-Cultural characteristics on their online purchase behaviour. The analysis result in the present study disclosed some interesting results. In our society it is very famous that Social factors are very important factor in consumer behaviour. But in our research, it had been found that various social factors variables i.e. Respondents' Reference Group, their friends, their family and their Status do not have significant influence on their online shopping behaviour. This study result is denying the view that Social factors influence the customers' purchase behaviour when they are online. This analysis result is contrary to Tan (1999) study findings in which they admitted that high social status people are influenced by their social status with regard to online shopping. This could happen because nowadays there is a revolution in IT area and access to internet is much simpler compared to few years ago. After access to internet, consumers explore the market for their own convenience. In this case all types of consumers are using this facility and hence the social factors are not much significant in online purchase behaviour.

In the second case it has been found that among the eight variables of Cultural factors only three variables Respondents' Values, their Language and their Country Law were found to be most influencing variables. This is a fact that values of a person are necessary component of a persons' behaviour. In this case this behaviour also influences the person when he buys his convenience product and according to the analysis result the person will purchase online according to his values. Language is also an important variable of demography for any individual. Human beings think in his language and when he purchases online if the language of the advertisement or product description is not to customers' convenience it can affect the purchase behaviour of that particular individual. The country law where an individual live is also an important factor which influences the person in various ways. In case of online shopping what type of product he wants and what is the law of that country regarding that product matters very much like as alcoholic materials, wines etc. are not permitted in some countries in the world.

In the third case analysis result showed that three variables out of five variables i.e. Respondents' Education, Occupation and Income have significant influence on online shopping behaviour of customers. This analysis result confirms the study findings of Case et al. (2001); Hasslinger et al., (2007); Li. Et al., 1999; Ansari, 2016; Mareeswaran \& Sunderaraj (2017); Farooqi and Ansari (2017) in which they found that customers' online shopping behaviour is influenced by their education, occupation and income. This part of analysis contrary to study results of Muthumani \& Rajayogan (2017) in which they found that occupation of consumers do not have significant influence on their online purchase behaviour. It is natural that if a person is much educated, he will have the better knowledge of the world and market in contrast to uneducated or less educated person. In this case that person can make several combinations and choices with the help of his knowledge in online shopping. A person whose occupation is of much earning nature could purchase more than the less earning occupation. This also matters much in online shopping or any other area of life where the matter is related to money and finance. As it is known fact

www.jbrmr.com A Journal of the Academy of Business and Retail Management (ABRM) 
that income of any person is the most dominant factor regarding any financial issue. Online shopping is financial issue because a lot of money is being spent in this. Hence while shopping online the individual will always keep in mind his income and according to this, he will spend his money. In overall analysis process it has been observed that the third factor i.e. "Social Class" factor comprising five variables in which three most dominating variables carrying mean value higher than 4.00 is the most dominating factor among all three factors. Here in overall it had been found that customers" Socio Cultural factors have a significant influence on their online shopping behaviour which is enough evidence to reject the framed hypothesis that 'Socio Cultural factors of the respondents do not have significant influence on their online shopping behaviour'.

\section{Conclusion}

The present study has been carried out taking the objective to assess the influence of Customers' Socio-Cultural Factors on their online shopping behaviour. For this purpose, 400 respondents had been selected from Saudi citizens and non-Saudi residents living in Saudi Arabia. A close ended structured questionnaire had been used as research instrument. Result of Factor analysis showed that all the factors were highly reliable for the study. Three factors captioned Social factors, Cultural factors and Social Class has been extracted with 4, 8 and 5 variables respectively. Analysis results demonstrate that the first factor Social Factors with 4 variables had not any significant influence on online shopping behaviour of customers. The second factor named Cultural Factors with eight variables had a significant influence on online shopping behaviour. In this factor three variables with mean value higher than 4.00 were making significant variance. The third factor captioned Social Class was found to be most dominant factor with five variables in which three variables has mean value more than 4.00 and they were making a very highly significant in influence on online shopping behaviour of Customer.

\section{Study Limitations}

As we know every study has its own limitations therefore the present study also comes under this category. Present study has been carried out in Saudi Arabia and inference from this study is only applicable in Saudi Arabia. Same study with same factors and methodology could also be applied in other part of the globe for generalizations of the findings. Researcher has considered only three dimensions of demographics of customers. Other dimensions could also be explored in this regard. Some other factors which also influence customers' online behaviour which are not yet searched could also be explored.

\section{References}

Adnan, H. (2014). An Analysis of the Factors Affecting Online Purchasing Behavior of Pakistani Consumers. International Journal of Marketing Studies, 6(5), 133-148. http://doi.org/10.5539/ijms.v6n5p133.

Ansari, Z. A. (2016). Online Shopping Behaviour in Saudi Arabia: An Empirical Study. International Journal of Advanced Research, 4(5), 689-697.

Ansari, Z. A. \& Alhazemi, A., (2016). An Empirical Study of the Consumer Awareness and Acceptance of Online Shopping in Saudi Arabia. International Journal of Development Research, 6(02), 6918-6925.

Bashir, A. (2013). Consumer Behavior towards online shopping of electronics in Pakistan. Ph. D. Thesis. Seinäjoki University of Applied sciences, West Finland.

Case, T., Burns, O. M., \& Dick, G. (2001). Drivers of on-line purchasing among US university students. AMCIS 2001 Proceedings, 169

Chen, N. \& Hung, Y. (2015). Online Shopping Orientation and Purchase Behavior for High-Touch Products. International Journal of Electronic Commerce Studies, 6(2), 187-202.

Elliot, S. \& Fowell, S. (2000). "Expectations versus reality: a snapshot of consumer experience with Internet retailing", International Journal of Information Management, 20(5), 323-36.

Falode, B. O., Amubode, A. A., Adegunwa, M. O. \& Ogunduyile, S. R. (2016). Online and Offline Shopping Motivation of Apparel Consumers in Ibadan Metropolis, Nigeria. International Journal of Marketing Studies, 8(1), 150-160.

Farooqi, R. \& Ansari, S. (2017). Moderating effect of Demographic Variables on Attitude towards Online Shopping: An Empirical Study Using PROCESS. Journal of Business and Management, 19(11), 47-54.

Ferri, F., Grifoni, P., \& Guzzo, T. (2008), Social Aspects of Mobile Technologies on the Web Tourism Trend. Handbook of research on mobile business: technical, methodological and social perspectives. In Bhuvan Unhelkar (Ed), IGI Global, 293 - 303. http:/ / dx.doi.org/10.4018/978-1-60566-156-8.ch027 
Goldsmith, R. E., Bridges, E. and Freden, J. (2001). Characterizing online buyer: Who goes with the flow? Quarterly Journal of Electronic Commerce, 2(3), 189-197.

Hasslinger, A., Hodzic, S. \& Obazo, C. (2007), "Consumer behaviour in online shopping", Kristianstaad University Department of Business Studies.

Global online retail spending - Statistics and Trends (2018), https://www.invespcro.com/blog/global-online-retailspending-statistics-and-trends/ (Accessed on : 1-May-2018)

Jarvenpaa, S. L. and Grazioli, S. (1999). Surfing among the sharks: How to gain trust in the cyberspace. Financial Times Supplement, 15 March.

Korgaonkar, P. K., \& Wolin, L. D. (1999). “A Mulitvariate analysis of web usage”, Journal of Advertising Research, 39(2), 53-68.

Li, H. K. C., \& Russel, M. G. (1999), “The impact of perceived channel utilities, shopping orientations, and demographics on the consumers"e online buying behaviour", Journal of Computer-Mediated Communications, 5(2), 2-25.

Mareeswaran, K., \& Sunderaraj, R. (2017). Online Buying Behaviour of Shoppers in Sivakasi, Tamil Nadu. Asian Review of Social Science, 6(1), 37-41.

Muthumani, S., \& Rajayogan, K. (2017). A Study on Factors Influencing Online Buying Behaviour with Chennai Consumers. Indian Journal of Science and Research, 14(1), 79-82.

Nazir, S., Tayyab, A., Sajid, A., Rashid, H., \& Javed, I. (2012). “How Online Shopping Is Affecting Consumers Buying Behavior in Pakistan?" Abstract: Introduction: Research Objectives: Literature Review: International Journal of Computer Science, 9(3), 486-495.

Ngugi, K. (2014). Factors Influencing Online Shopping Adoption in Kenya: A Case of Westlands District, Nairobi A Research Project Report Submitted In Partial Fulfillment of The Requirements For The Award Of The Degree Of Master Of Arts In Project Planning And Management. University of Nairobi.

Reichheld F. \& Schefter, P. (2000). “E-loyalty: your secret weapon on the web”, Harvard Business Review, 78(4), 105-15.

Rodgers, S., \& Harris, M. (2003). Gender and e-commerce: an exploratory study. Journal of Advertising Research, 43(3), 322-329. http://dx.doi.org/10.1017/S0021849903030307

Seiders, K., Voss, G. B., Grewal, D., \& Godfrey, A. L. (2005). Do Satisfied Customers Buy More? Examining Moderating Influences in a Retailing Context. Journal of Marketing, 69, 26-43.

Slyke, C., Lou, H., Belanger, F., \& Sridhar, V. (2002). The influence of culture on consumer-oriented electronic commerce adoption. Proceedings of the 7th annual conference of the Southern Association for Information Systems, 310-315.

Soopramanien, D. G. R., \& Robertson, A. (2007). Adoption and usage of online shopping: An empirical analysis of the characteristics of "buyers" "browsers" and "non-internet shoppers." Journal of Retailing and Consumer Services, 14(1), 73-82. http:/ / doi.org/10.1016/j.jretconser.2006.04.002.

Vellido, A., Lisboa, P. J. G. and Meehan, K. (2000). Quantitative characterization and prediction of online purchasing behavior: A talent variable approach. International Journal of Electronic Commerce, 4(4), 83-104.

Violino, B. (2000), “E-Business lurches abroad”, Internet Week, March 19, available at: www.internetweek.com

Walker, O.C., \& Mullins J.W. (2014), “Marketing Strategy- A decision - Focused Approach”, McGraw Hill International Edition, 8e, Singapore.

Wallis, G. (2006), “Internet spending: measurement and recent trends”, Economic Trends, 628.

Yin-Fah, B. C., \& Hooi-Choo, B. (2010). Undergraduates and Online Purchasing Behavior. Asian Social Science, 6(10), 133-146.

Zheng, F. (2006). Internet shopping and its impact on consumer behavior. Master research in the University of Nottingham, 65-90. 